\title{
Effects of dimethyl ether on n-butane oxidation
}

\author{
Tugce Bekat ${ }^{\mathrm{a}}$, Fikret Inal ${ }^{\mathrm{b}, *}$ \\ a Department of Chemical Engineering, Yildiz Technical University, Esenler 34220 Istanbul, Turkey \\ ${ }^{\mathrm{b}}$ Department of Chemical Engineering, Izmir Institute of Technology, Gulbahce-Urla 35430 Izmir, Turkey
}

\section{H I G H L I G H T S}

- Effects of DME addition to n-butane oxidation were studied.

- DME was found to decrease the formations of CO, aromatic species and PAHs.

- DME addition increased the formations of formaldehyde and acetaldehyde.

- Effects of equivalence ratio were investigated in fuel-rich conditions.

- Increasing equivalence ratio increased the formations of aromatic and PAH species.

\section{A R T I C L E I N F O}

\section{Article history:}

Received 19 July 2012

Received in revised form 2 October 2012

Accepted 27 November 2012

Available online 28 December 2012

\section{Keywords:}

Dimethyl ether

Oxygenated additives

n-Butane

Equivalence ratio

\begin{abstract}
A B S T R A C T
Dimethyl ether (DME) is the simplest ether and it is used as an alternative fuel or fuel additive to reduce toxic emissions from combustion processes. The effects of DME on n-butane oxidation were investigated for two different concentrations of DME in the fuel mixture (i.e., 20\% and 50\%) and two different fuel-rich equivalence ratios (i.e., 2.6 and 3.0) using detailed chemical kinetic modeling. Reactor model was selected as atmospheric-pressure, adiabatic, tubular reactor, operated under laminar flow conditions. The concentration profiles of major, minor, and trace species were obtained for n-butane/DME/oxygen/argon at six different reactor inlet temperatures, and the results were compared with those attained for pure n-butane oxidation case (n-butane/oxygen/argon). Dimethyl ether addition decreased formations of various toxic species such as carbon monoxide, aromatic species, and polycyclic aromatic hydrocarbons, while it increased the formations of formaldehyde and acetaldehyde. Increasing equivalence ratio increased the formations of carbon monoxide, methane, aromatic species, and polycyclic aromatic hydrocarbons, while its effects on formaldehyde and acetaldehyde were not pronounced under the conditions studied.
\end{abstract}

(๑) 2012 Elsevier Ltd. All rights reserved.

\section{Introduction}

One of the major sources of current environmental pollution is the toxic air pollutants released from combustion and oxidation processes utilized in manufacturing, transportation, and power generation industries. Formations of these hazardous compounds are related to the oxidation chemistries of fuels and process conditions. Theoretical modeling is one of the most widely used methods for investigation of oxidation processes and formations of oxidation products. The conversions of the reactants into different products are described by detailed chemical kinetic modeling at molecular level.

Fuels utilized currently are almost totally composed of hydrocarbons. n-Butane $\left(\mathrm{C}_{4} \mathrm{H}_{10}\right)$, one type of hydrocarbon fuel, is an alkane that is widely used in internal combustion engines,

\footnotetext{
* Corresponding author. Tel.: +90 (232) 750 6654; fax: +90 (232) 7506645 .

E-mail address: fikretinal@iyte.edu.tr (F. Inal).
}

industrial burners, and residential heating, and is a main component of LPG (liquefied petroleum gas). Although it is known to be a cleaner fuel producing lower emissions compared to gasoline and diesel; there are still some types of emissions such as CO, polycyclic aromatic hydrocarbons (PAHs), and soot, associated with the usage of n-butane, especially at fuel-rich conditions. These compounds are known to be toxic or carcinogenic [1].

The addition of oxygenated fuel-additives to hydrocarbon fuels is one of the methods applied in reduction of hazardous emissions from oxidation processes. Dimethyl ether (DME, $\left.\mathrm{CH}_{3} \mathrm{OCH}_{3}\right)$, one of these oxygenated additives, is the simplest ether with an oxygen atom in its structure. It does not contain any $\mathrm{C}-\mathrm{C}$ bonds and has the lowest $\mathrm{C} / \mathrm{H}$ ratio after methane. Its handling characteristics are similar to butane and propane.

DME can be produced from variety of sources such as natural gas, coal, and biomass. Worldwide DME production capacity and actual market use have been reported to be about 10 million metric tons per year and 3 million metric tons per year, respectively [2]. China is the leader country in DME production and use. Currently, 
more than $90 \%$ of DME produced in China is used as a LPG blend stock for domestic uses. Other leading markets for DME are; transportation fuel, fuel for power generation, and chemical feedstock for olefins and gasoline $[2,3]$.

Marchionna et al. [4] have investigated the potential application of DME as a substitute fuel in domestic appliances commonly fed with LPG. Five cooking hobs with three different types of burners were used in the experiments. The results showed that while the use of pure DME requires making a few changes to the burners, 15-20 vol\% DME in a mixture of DME/LPG (LPG: C3/C4 ratio of $65 / 35$ ) could be utilized without any modification of standard equipment used for pure LPG. The positive effects of DME addition to LPG were also observed with respect to $\mathrm{CO}$ and $\mathrm{NO}$ emissions.

$\mathrm{CO}$ and NO emissions from DME and conventional utility fuels propane and $n$-butane were also studied in laminar premixed flames on the basis of constant mass flow $(0.3 \mathrm{~g} / \mathrm{min})$, constant $\mathrm{C}$-atom flow normalized to n-butane, and constant energy release rate of $100 \mathrm{~J} / \mathrm{s}$ over a wide range of equivalence ratios [5]. The results indicated that while lower $\mathrm{CO}$ emission was obtained from DME fuel on all three bases, NO production was generally less than or similar to that of propane and n-butane.

Due to its superior physical and chemical properties such as high cetane number $(>55)$, low boiling point, low auto-ignition temperature, and simultaneous reductions in $\mathrm{NO}_{x}$ and smoke emissions, DME has been considered as a potential diesel engine fuel. Pure diesel and DME were used to study exhaust $\mathrm{CO}, \mathrm{NO}_{x}$, total hydrocarbon (THC), smoke, and formaldehyde emissions from a
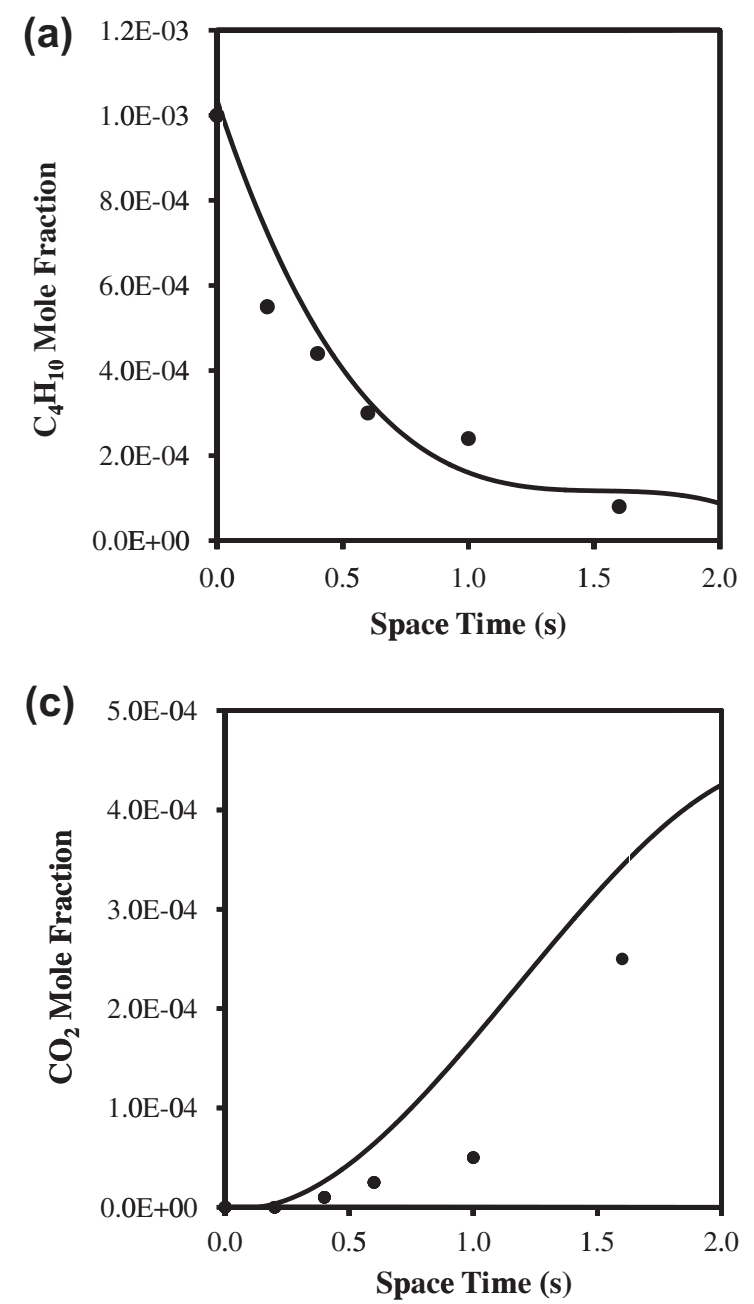

four-stroke, two-cylinder, direct injection diesel engine at two engine speeds (1400 rpm and $1870 \mathrm{rpm}$ ) [6]. $\mathrm{CO}$ and $\mathrm{NO}_{x}$ emissions were decreased by $59 \%$ and $45.2 \%$ at $1400 \mathrm{rpm}$, and $23.7 \%$ and $57.9 \%$ at $1870 \mathrm{rpm}$, respectively when DME was used as a fuel. The THC emissions from DME fuel were close to that from diesel fuel. Smoke emission was almost zero for DME under the experimental conditions investigated. However, formaldehyde emission with DME was slightly higher than that with diesel fuel. Xinling and Zhen [7] have also reported substantial reductions in THC (40.1\%) and $\mathrm{NO}_{x}(48.2 \%)$ emissions from a 6-cylinder, mediumduty, direct injection, turbocharged diesel engine for DME compared with diesel fuel.

The performance, emissions characteristics, and combustion stability of a single cylinder compression ignition $(\mathrm{CI})$ engine operated with n-butane blended DME (0-40\% n-butane by mass) and diesel fuels were studied at $1500 \mathrm{rpm}$ [8]. The combustion stability of the blended fuel was better in comparison to diesel fuel, and stable engine operation was reported for a wide range of engine loads up to $30 \%$ n-butane by mass in n-butane/DME blend. The engine power output and fuel consumption were improved with n-butane/DME blend. CO and THC emissions were increased at low engine loads when fuel blend was used. Soot and $\mathrm{NO}_{x}$ emissions were similar for all blends. However, $\mathrm{NO}_{x}$ emissions for blended fuels were lower than those for diesel fuel.

The major drawbacks of DME as an alternative fuel for internal combustion engines compared with petroleum based conventional fuels are; its low enthalpy of combustion due to about $35 \%$ oxygen
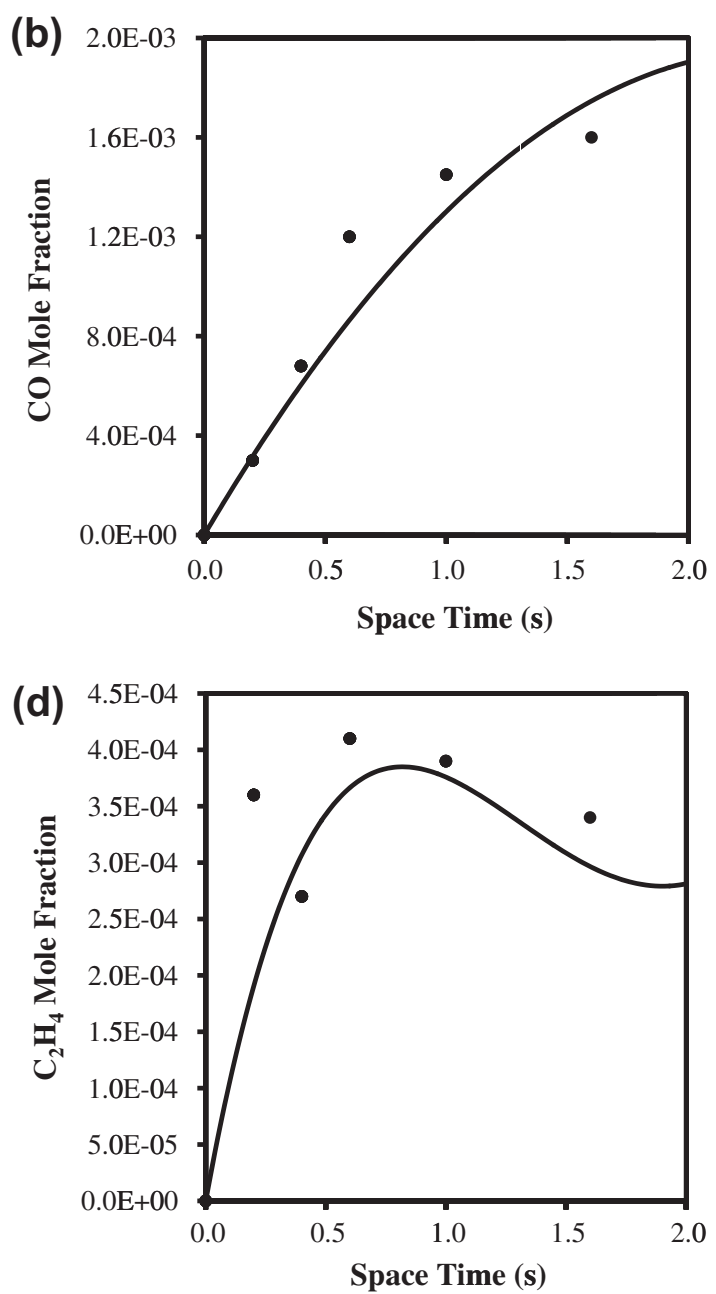

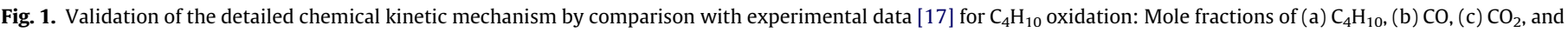
(d) $\mathrm{C}_{2} \mathrm{H}_{4}$. Lines show modeling results and the symbols correspond to experimental data. 

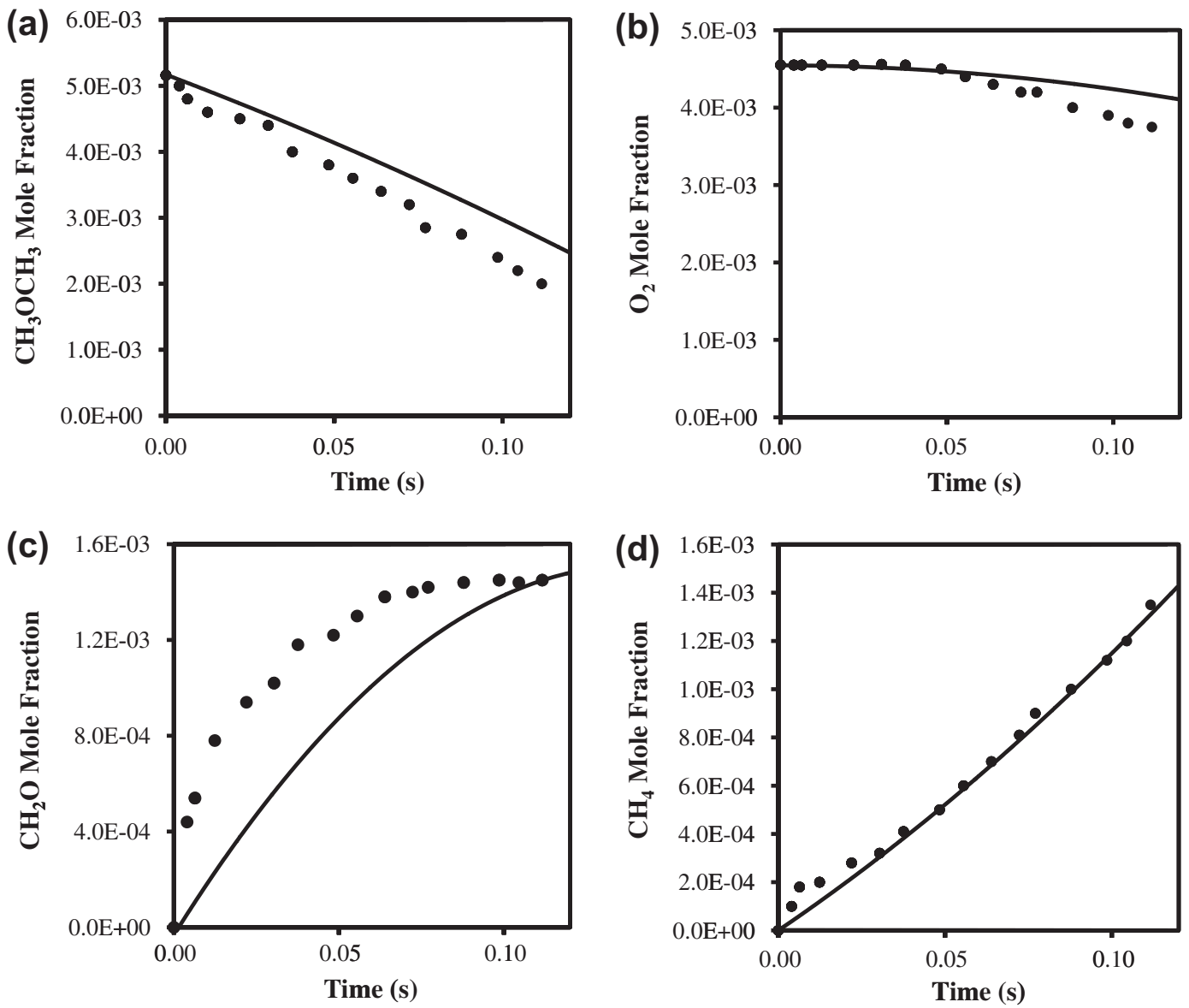

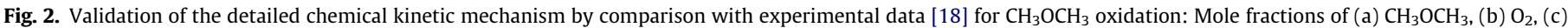
$\mathrm{CH}_{2} \mathrm{O}$, and (d) $\mathrm{CH}_{4}$. Lines show modeling results and the symbols correspond to experimental data.

Table 1

Inlet mole fractions of the fuels and the oxidizer in $\mathrm{C}_{4} \mathrm{H}_{10} / \mathrm{CH}_{3} \mathrm{OCH}_{3} / \mathrm{O}_{2} / \mathrm{Ar}$ oxidation system.

\begin{tabular}{lclll}
\hline Equivalence ratio, $\phi$ & Dimethyl ether (\%) & $X_{\mathrm{C}_{4} \mathrm{H}_{10}}$ & $X_{\mathrm{CH}_{3} \mathrm{OCH}_{3}}$ & $X_{\mathrm{O}_{2}}$ \\
\hline 2.6 & 0 & 0.0057 & 0.0 & 0.0143 \\
& 20 & 0.0049 & 0.0012 & 0.0138 \\
& 50 & 0.0035 & 0.0035 & 0.0129 \\
3.0 & 0 & 0.0063 & 0.0 & 0.0137 \\
& 20 & 0.0055 & 0.0014 & 0.0132 \\
& 50 & 0.0039 & 0.0039 & 0.0122 \\
\hline
\end{tabular}

content by mass, leakage and lubricity problems due to its low viscosity, and material compatibility problems with most of the elastomers due to its corrosive nature $[9,10]$. Therefore, some modifications to engine, fuel supply, and fuel injection systems are required for pure DME application in engines.

Although the major potential utilization of DME as an alternative fuel is for $\mathrm{CI}$ engines, there are also many studies in the literature on the application of DME/LPG blends in spark ignition (SI) engines. The performance, emission characteristics, and combustion stability of a $2.7 \mathrm{~L}$ SI engine operated with DME/n-butane blend containing 0-30\% DME (by mass) were investigated by Lee et al. [11]. Pure n-butane was used as LPG in the study. Stable engine operation was obtained for a wide range of engine loads up to 20\% (by mass) DME blended fuel. The engine power output was comparable to that of pure n-butane up to $10 \%$ DME concentration. However, for DME concentrations of greater than $10 \%$ in the fuel blend, engine power output was decreased and break specific fuel

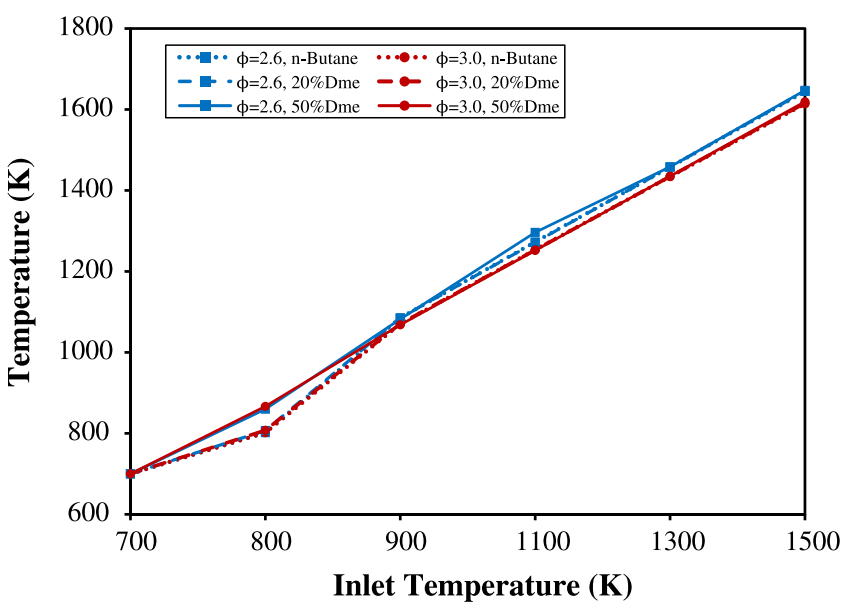

Fig. 3. Final reaction temperatures for different inlet temperatures.

consumption (BSFC) was increased. DME addition to n-butane also increased engine knock. At low engine speed, exhaust THC and $\mathrm{NO}_{x}$ emissions were slightly increased when DME blended fuel was used.

DME blended propane which has a higher octane number than n-butane was also tested in SI engine to reduce the engine knock problem [12]. At a concentration of $20 \%$ DME (by mass) in the fuel blend, stable engine operation was obtained for a wide range of engine loads with DME/propane blend rather than DME/n-butane 
blend. It has also been reported that engine power output, BSFC, and combustion stability were comparable to those acquired with LPG fuel when propane containing blend was used. The differences in emission levels of $\mathrm{CO}, \mathrm{THC}$, and $\mathrm{NO}_{x}$ were not significant for DME/propane and DME/n-butane blends.

Effects of DME addition to gasoline [13], methanol [14], and ethanol [15] on the performance of a modified $1.6 \mathrm{~L}$, four-cylinder SI engine were also investigated experimentally in the literature.

Aromatic species, PAHs, and soot were found to be reduced with the addition of DME to methane, ethane, propane [16,17], and LPG [4]. However, for ethylene, DME addition was observed to increase the formation of PAHs and soot $[17,18]$. Formaldehyde emissions were reported to increase with DME addition for LPG [4].

To our knowledge, there are no comprehensive studies in the literature investigating the effects of DME addition to n-butane. In this study, the aim was to analyze the formations of major, minor, and trace species in an atmospheric-pressure, adiabatic, tubular reactor for n-butane/DME/oxygen/argon system at two different DME concentrations and two different fuel-rich equivalence ratios using detailed chemical kinetic modeling technique. Equivalence ratio, $\phi$, is used to indicate quantitatively whether a fuel-oxidizer mixture is fuel-rich $(\phi>1)$, fuel-lean $(\phi<1)$, or stoichiometric $(\phi$ $=1$ ). The amount of the oxidation products formed, especially of the aromatic species and PAHs, are known to be related to the fuel-oxidizer equivalence ratio. Formations of aromatic species and PAHs are observed at fuel-rich conditions, and are known to increase with increasing equivalence ratio. Therefore, for the oxidation of n-butane and DME mixture, two different equivalence ratios at fuel-rich conditions ( $\phi=2.6$ and 3.0) were selected and the
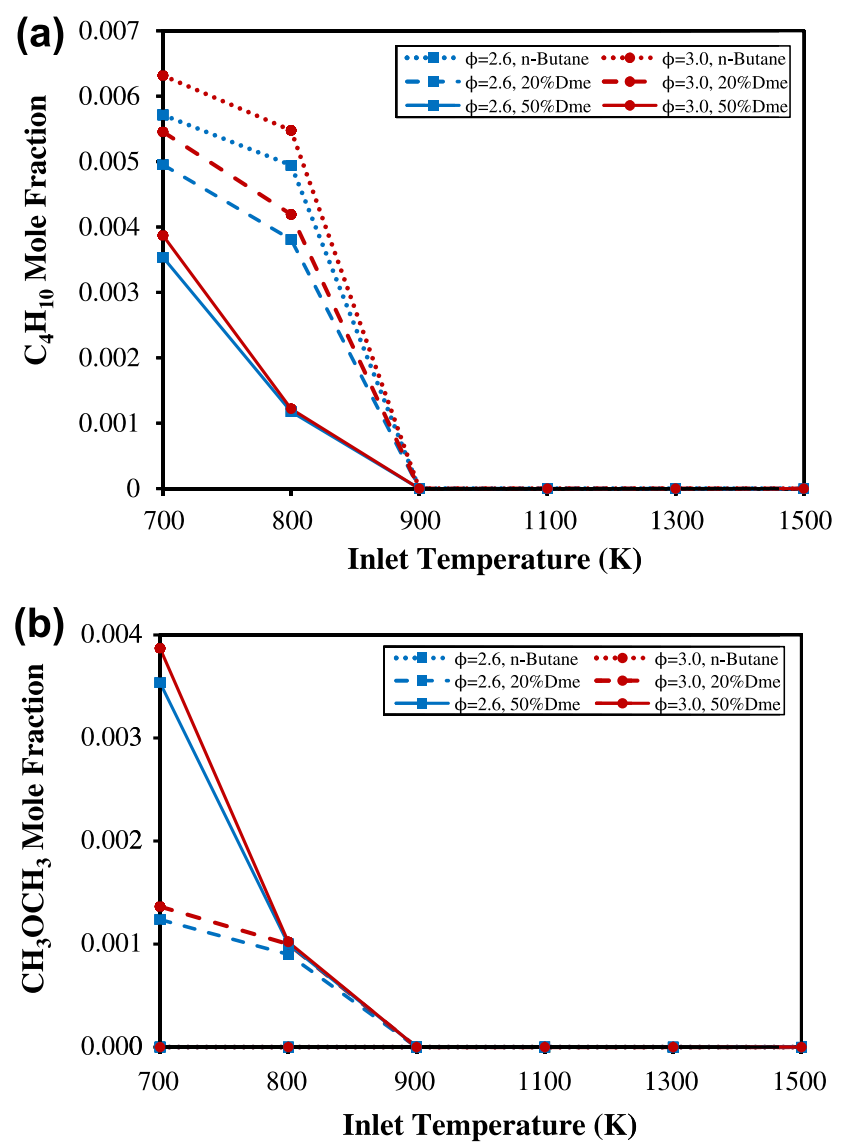

Fig. 4. Mole fractions of (a) n-butane and (b) dimethyl ether at the reactor outlet for different inlet temperatures. effects of equivalence ratio on the formations of oxidation products were investigated. The reactor inlet temperature was varied from $700{ }^{\circ} \mathrm{K}$ to $1500{ }^{\circ} \mathrm{K}$.

\section{Method}

The detailed chemical kinetic mechanism used in this study was developed by the combination of the oxidation mechanisms of $n$ butane [19] and DME [20]. This detailed mechanism consisted of 903 elementary reactions of 201 chemical species [21].

The accuracy of the detailed mechanism developed was validated by comparison with the experimental data available in the literature for both n-butane [22] and DME [23] oxidations. The experimental findings in the literature were reproduced by kinetic modeling at the same process conditions, using the detailed chemical kinetic mechanism developed.

Chakir et al. [22] studied n-butane oxidation in a jet-stirred reactor at $937^{\circ} \mathrm{K}$ and $10 \mathrm{~atm}$. The kinetic mechanism developed was used to reproduce their results at the same conditions. The model predictions and experimental data are given in Fig. 1 for $\mathrm{C}_{4} \mathrm{H}_{10}, \mathrm{CO}, \mathrm{CO}_{2}$ and ethylene $\left(\mathrm{C}_{2} \mathrm{H}_{4}\right)$. The detailed chemical kinetic mechanism developed could successfully reproduce the mole fractions of $\mathrm{C}_{4} \mathrm{H}_{10}$, $\mathrm{CO}$, and $\mathrm{C}_{2} \mathrm{H}_{4}$, while it slightly over predicted the mole fraction of $\mathrm{CO}_{2}$.

Fischer et al. [23] studied DME oxidation experimentally and theoretically in a flow reactor at $1086{ }^{\circ} \mathrm{K}$ and $1 \mathrm{~atm}$, and for an equivalence ratio of 3.4. Their experimental results were reproduced using the kinetic mechanism developed. The results of the
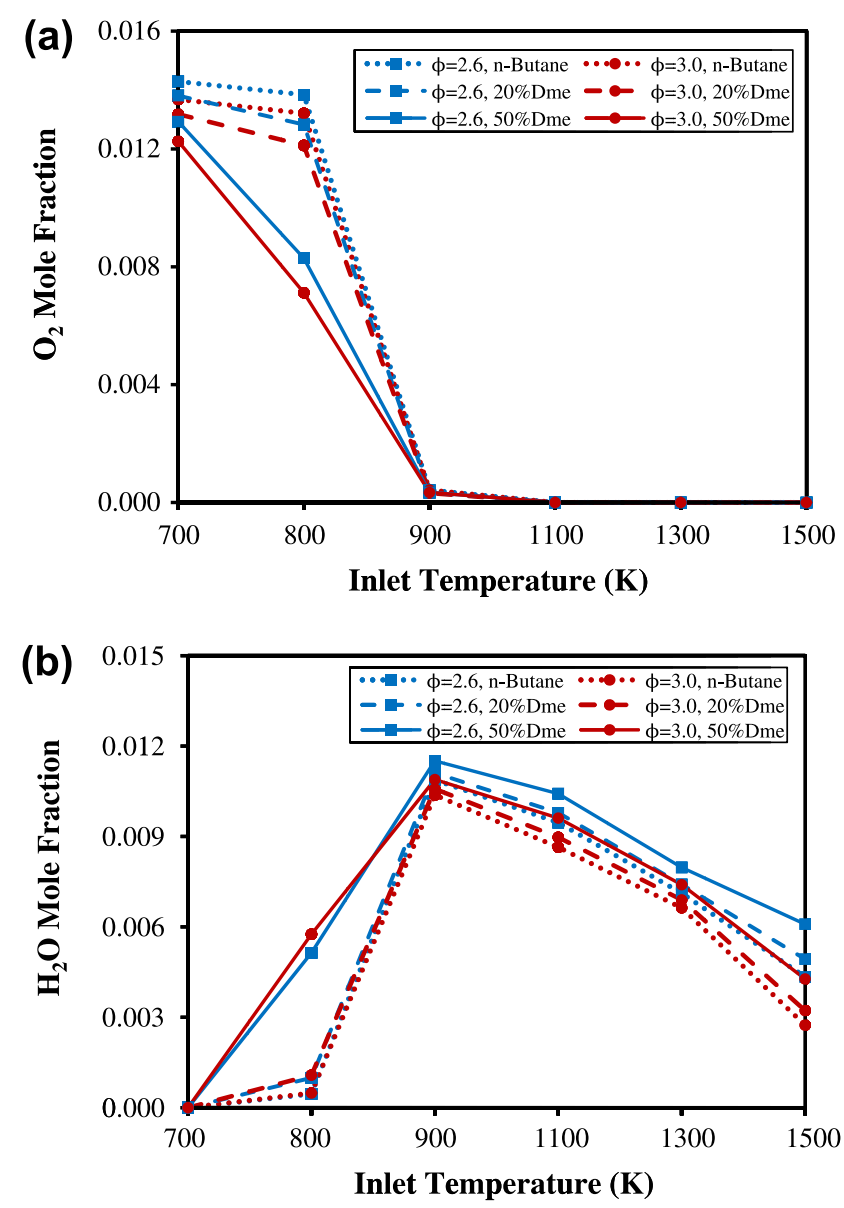

Fig. 5. Mole fractions of (a) $\mathrm{O}_{2}$ and (b) $\mathrm{H}_{2} \mathrm{O}$ at the reactor outlet for different inlet temperatures. 

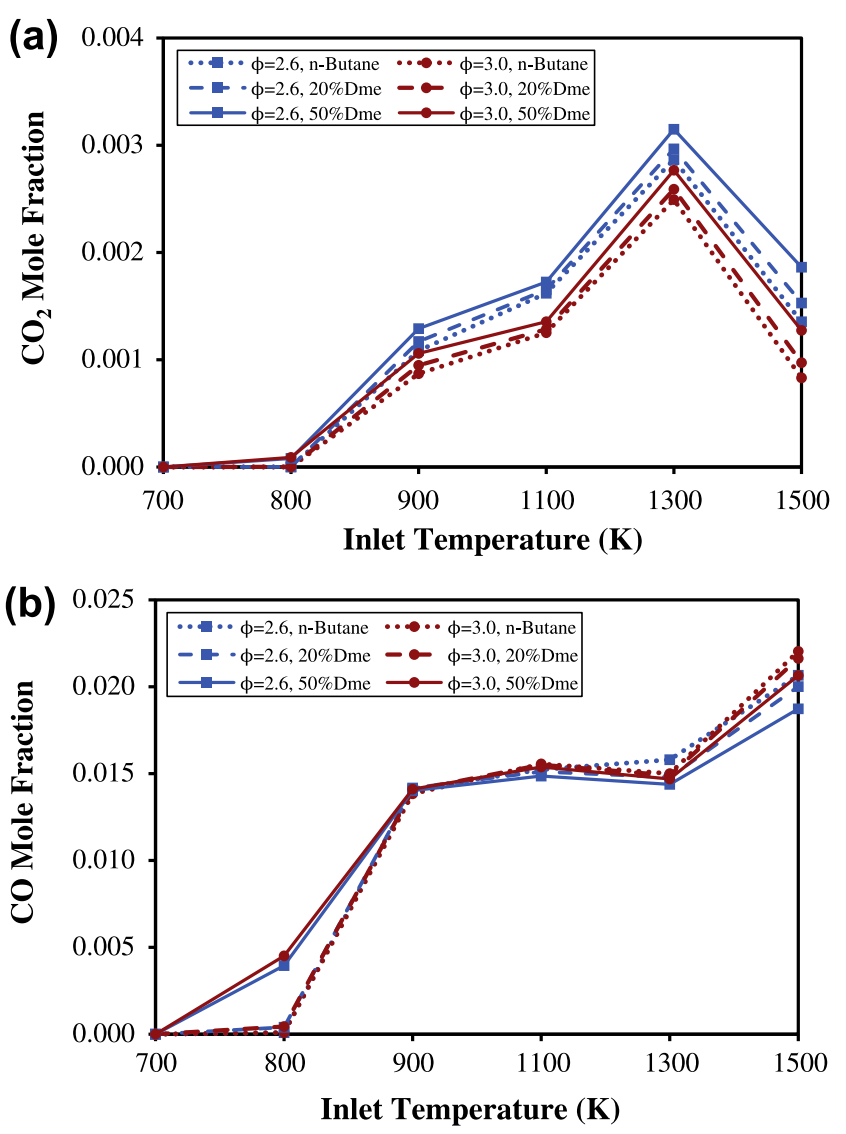

Fig. 6. Mole fractions of (a) $\mathrm{CO}_{2}$ and (b) $\mathrm{CO}$ at the reactor outlet for different inlet temperatures.

comparison between the experimental data and modeling predictions are given in Fig. 2 for $\mathrm{CH}_{3} \mathrm{OCH}_{3}, \mathrm{O}_{2}$, formaldehyde $\left(\mathrm{CH}_{2} \mathrm{O}\right)$, and methane $\left(\mathrm{CH}_{4}\right)$. The mole fractions of $\mathrm{CH}_{3} \mathrm{OCH}_{3}, \mathrm{O}_{2}$, and $\mathrm{CH}_{4}$ were well predicted by the mechanism, while mole fraction of $\mathrm{CH}_{2} \mathrm{O}$ was slightly under predicted. Based on these findings, it can be said that the detailed chemical kinetic mechanism developed could successfully predict the mole fractions of various species for the oxidations of n-butane and DME.

Modeling of the n-butane/DME/oxygen/argon system was performed with CHEMKIN-PRO ${ }^{\circledR}[24]$ software, and a tubular reactor with $10 \mathrm{~m}$ length and $0.05 \mathrm{~m}$ diameter was used for the oxidation process. Flow through the reactor was carried out in laminar flow conditions with a velocity of $0.5 \mathrm{~m} / \mathrm{s}$. Plug flow was assumed within the reactor and this assumption was validated according to the dispersion model [25]. The dispersion coefficients calculated for all conditions studied were smaller than 0.01 , indicating the validity of the plug-flow assumption. The reactor was operated adiabatically at constant atmospheric-pressure. Six different inlet temperatures $\left(T_{0}=700,800,900,1100,1300\right.$, and $\left.1500^{\circ} \mathrm{K}\right)$ were studied, and the concentration profiles of major, minor, and trace species were obtained.

Two different ratios of DME in the inlet fuel mixture (20\% and $50 \%$ ) were studied and the results were compared with those obtained for the oxidation of pure n-butane, in terms of the formations of the oxidation products. The inlet mole fractions of the reactants calculated according to two equivalence ratio values $(\phi$ $=2.6$ and 3.0), and for different mole fractions of DME in the fuel mixture, are given in Table 1 . Argon was used as a diluent gas in the reactor feed mixture, and its mole fraction was kept at 0.98 for all conditions. (a)

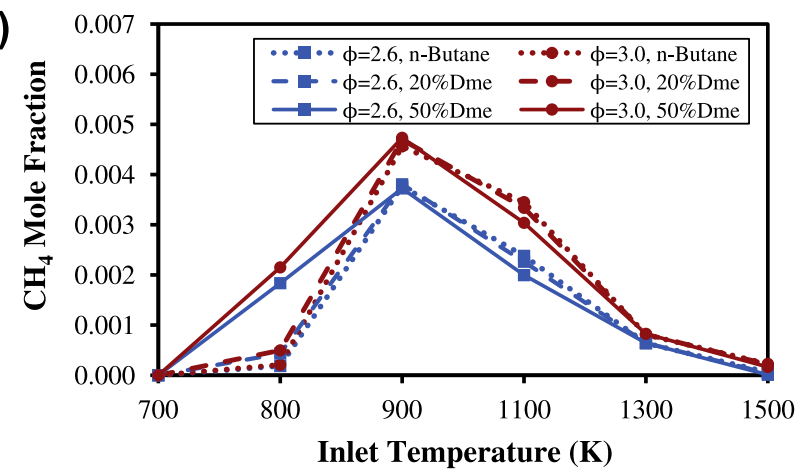

(b)

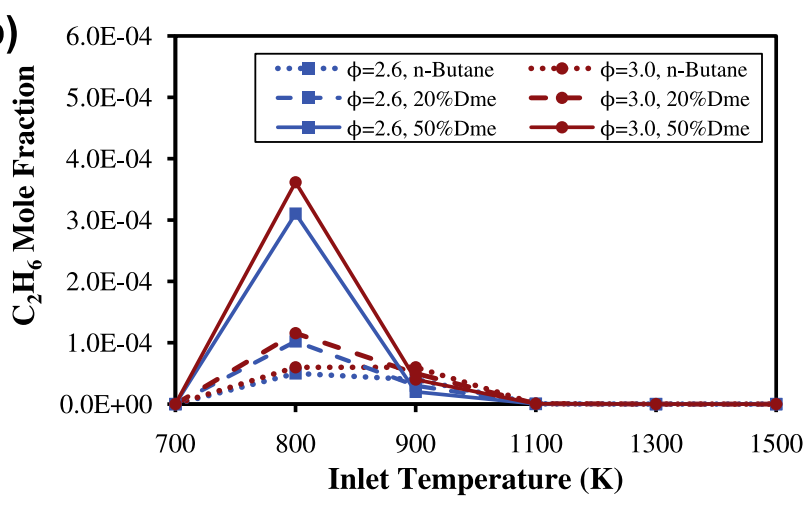

(c)

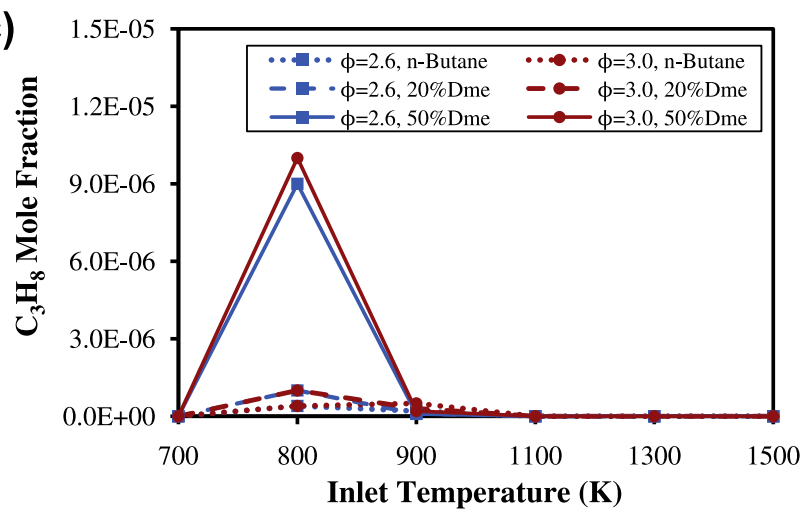

Fig. 7. Mole fractions of (a) methane, (b) ethane, and (c) propane at the reactor outlet for different inlet temperatures.

\section{Results and discussion}

Mole fractions of various oxidation products at the reactor outlet were obtained for different inlet temperatures, and compared for three different mole fractions of DME ( $0 \%$ (pure n-butane), $20 \%$, and $50 \%$ ) in the fuel mixture and for two different equivalence ratios (2.6 and 3.0). Final reaction temperatures at the reactor outlet are given in Fig. 3. Final reaction temperatures increased almost linearly with increasing inlet temperatures. The effects of DME mole fraction and equivalence ratio did not seem to have a significant effect on the final reaction temperature, since the temperature rise during reaction was kept at very low levels with $\mathrm{Ar}$ dilution.

Fig. $4 \mathrm{a}$ and $\mathrm{b}$ shows the final mole fractions of $\mathrm{n}$-butane and DME, respectively. It can be observed that the fuels were not totally consumed at the reactor outlet for the inlet temperatures lower than $900{ }^{\circ} \mathrm{K}$, where the overall rate of reaction was considerably slow. For the higher equivalence ratio value, the inlet mole fractions of the fuels were higher, and therefore, the outlet mole 

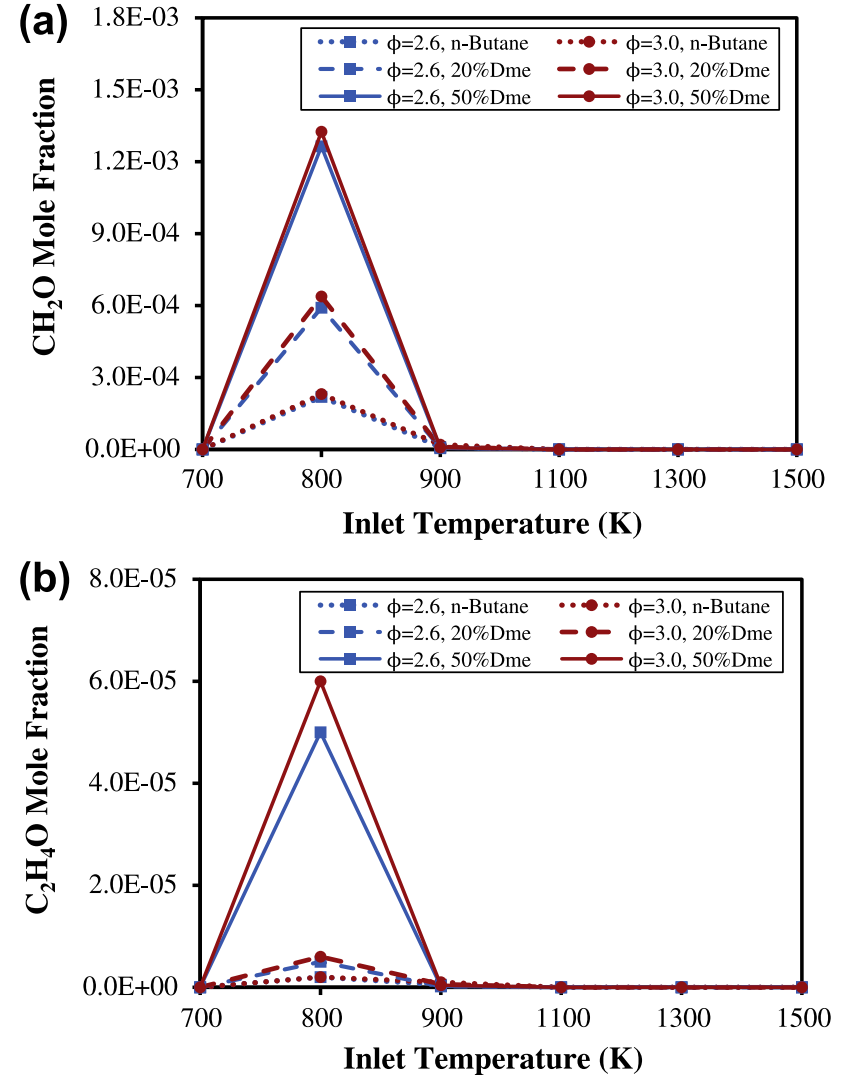

Fig. 8. Mole fractions of (a) formaldehyde and (b) acetaldehyde at the reactor outlet for different inlet temperatures.
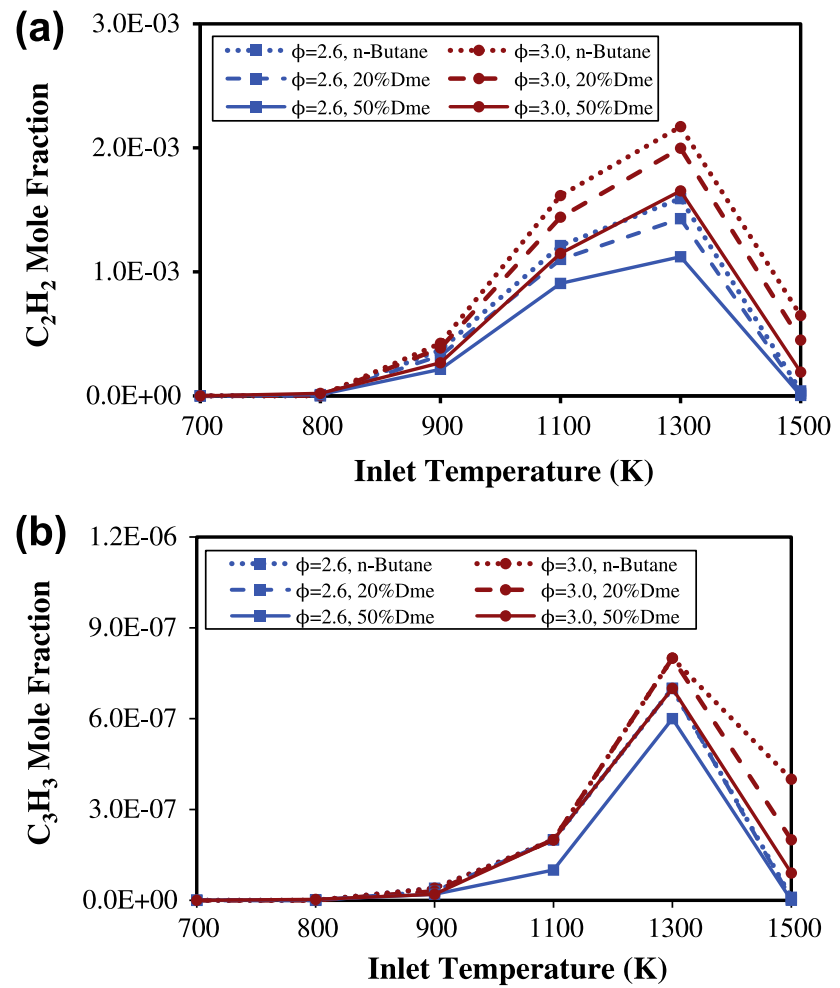

Fig. 9. Mole fractions of (a) acetylene and (b) propargyl at the reactor outlet for different inlet temperatures.
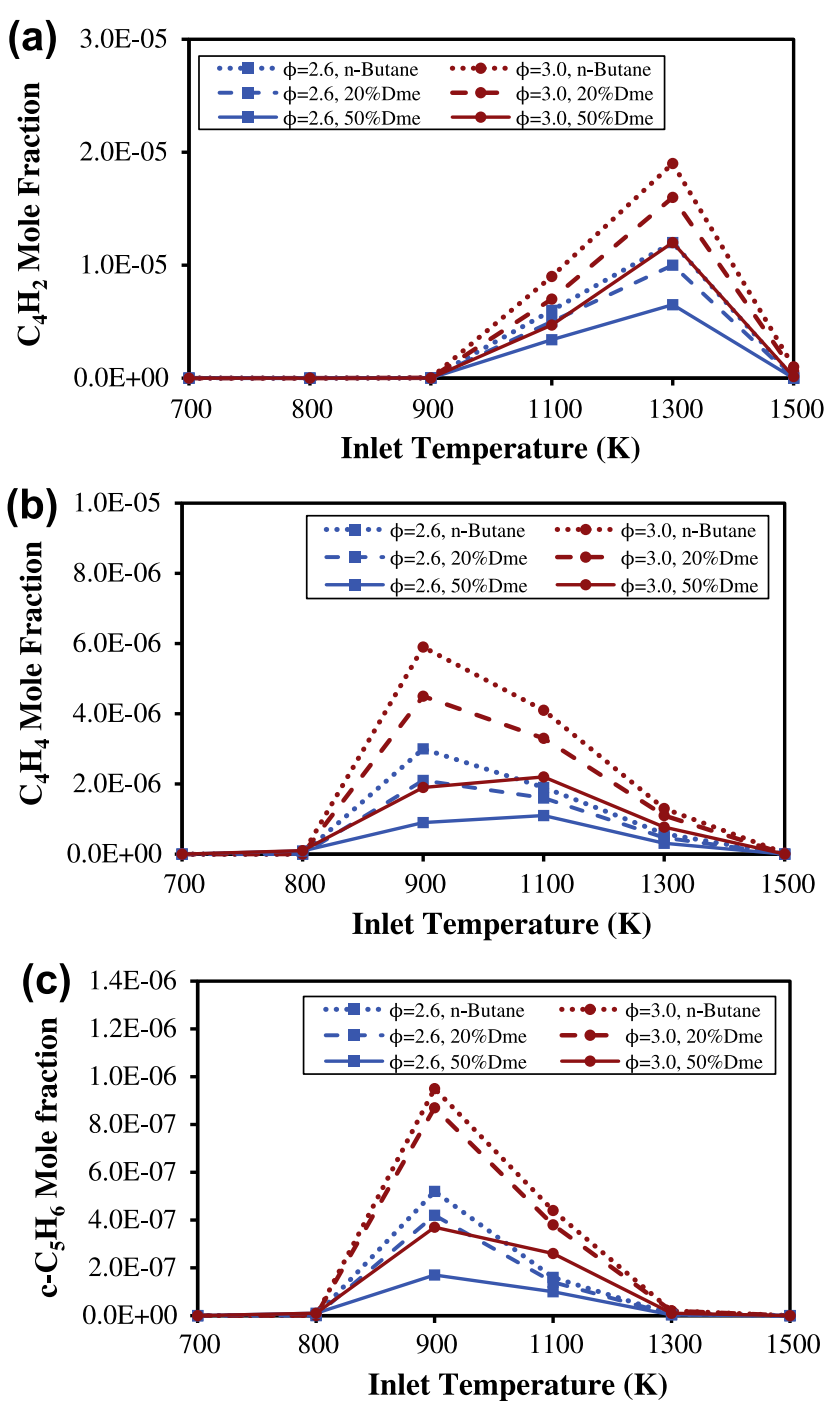

Fig. 10. Mole fractions of (a) diacetylene, (b) vinylacetylene, and (c) cyclopentadiene at the reactor outlet for different inlet temperatures.

fractions were also higher for inlet temperatures lower than $900{ }^{\circ} \mathrm{K}$. For the inlet temperatures of $900{ }^{\circ} \mathrm{K}$ and higher, n-butane and DME were totally consumed at the reactor outlet.

Fig. 5a shows the final mole fractions of the oxidizer, $\mathrm{O}_{2}$, at the reactor outlet. For the inlet temperatures lower than $900{ }^{\circ} \mathrm{K}, \mathrm{O}_{2}$ was not totally consumed due to the slow reaction rate, similar to the fuels. For the higher equivalence ratio value, the inlet mole fractions of $\mathrm{O}_{2}$ were lower, and the outlet mole fractions were also lower, for the inlet temperatures lower than $900{ }^{\circ} \mathrm{K}$. For inlet temperatures of $900{ }^{\circ} \mathrm{K}$ and higher, $\mathrm{O}_{2}$ was totally consumed at the reactor outlet.

$\mathrm{H}_{2} \mathrm{O}$ is one of the major oxidation products and its mole fractions at the reactor outlet are given in Fig. 5b. The effect of equivalence ratio was apparent for the inlet temperatures of $900{ }^{\circ} \mathrm{K}$ and higher. Increasing equivalence ratio decreased the mole fractions of $\mathrm{H}_{2} \mathrm{O}$. Increasing DME mole fraction increased the mole fractions of $\mathrm{H}_{2} \mathrm{O}$ at the reactor outlet. Since DME is an oxygenated compound, the increase in the mole fractions of species containing oxygen was expected. The mole fractions of $\mathrm{H}_{2}$, and $\mathrm{H}$ and $\mathrm{OH}$ radicals were also observed to increase with the addition of DME, according to our kinetic mechanism. Maximum mole fraction of $\mathrm{H}_{2} \mathrm{O}$ at the reactor outlet was observed for the inlet temperatures of about $900{ }^{\circ} \mathrm{K}$. 

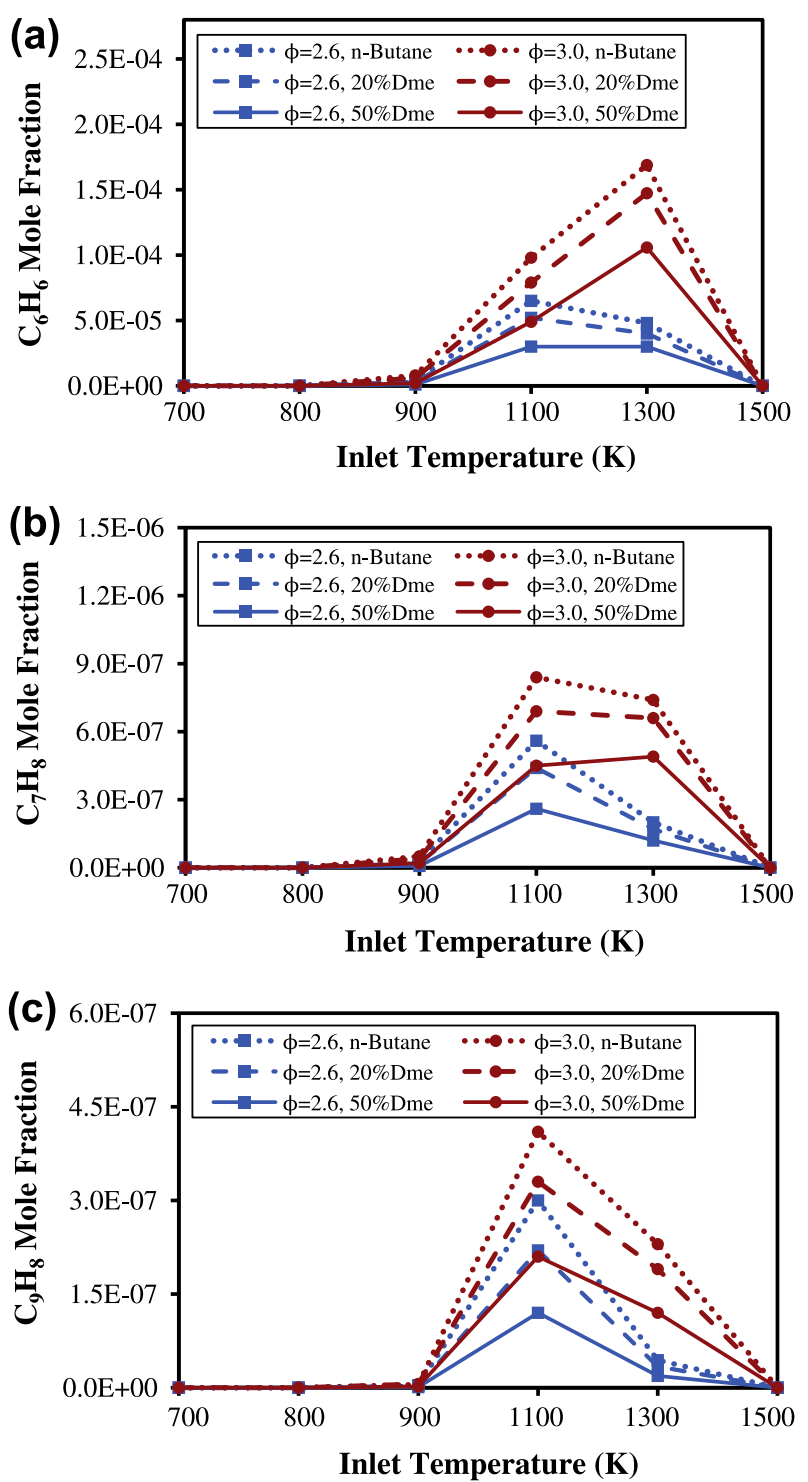

Fig. 11. Mole fractions of (a) benzene, (b) toluene, and (c) indene at the reactor outlet for different inlet temperatures.

Two other major oxidation products are $\mathrm{CO}_{2}$ and $\mathrm{CO}$, and their mole fractions at different inlet temperatures are shown in Fig. $6 a$ and b, respectively. Increase in the mole fraction of DME increased mole fractions of $\mathrm{CO}_{2}$ while it decreased mole fractions of $\mathrm{CO}$. The increase in $\mathrm{CO}_{2}$ and decrease in $\mathrm{CO}$ suggested a shift from partial oxidation to complete oxidation. Previously, Frye et al. [5] suggested that DME produced lower CO emissions than propane and butane; and Lee et al. [12] suggested that DME addition to n-butane and LPG decreased the emissions of $\mathrm{CO}$, in conformity with the results obtained in this study. Effect of DME mole fraction on the mole fractions of $\mathrm{CO}_{2}$ and $\mathrm{CO}$ seemed to become more dominant at higher temperatures. Oxygenated structure of DME was considered to increase the mole fractions of $\mathrm{CO}_{2}$ and $\mathrm{H}_{2} \mathrm{O}$ as a result of the reaction $\mathrm{HCOH}+\mathrm{O}_{2}=\mathrm{CO}_{2}+\mathrm{H}_{2} \mathrm{O}$. As the mole fraction of $\mathrm{CO}_{2}$ increased, the mole fractions of $\mathrm{CO}$ and $\mathrm{CH}_{2} \mathrm{O}$ were considered to be also increasing by the reaction $\mathrm{CH}_{2}+\mathrm{CO}_{2}=\mathrm{CH}_{2} \mathrm{O}+\mathrm{CO}$. Then, the mole fraction of $\mathrm{CO}$ might have decreased by the reaction $\mathrm{CO}+\mathrm{OH}=\mathrm{CO}_{2}+\mathrm{H}$, producing $\mathrm{CO}_{2}$, due to the increase in $\mathrm{OH}$ radicals. Decrease in the mole fraction of $\mathrm{CO}$ was important since $\mathrm{CO}$ is an important environmental emission. $\mathrm{CO}$ emissions generally increased as the inlet temperature was increased. The effect of equivalence ratio also became more dominant as the inlet temperature
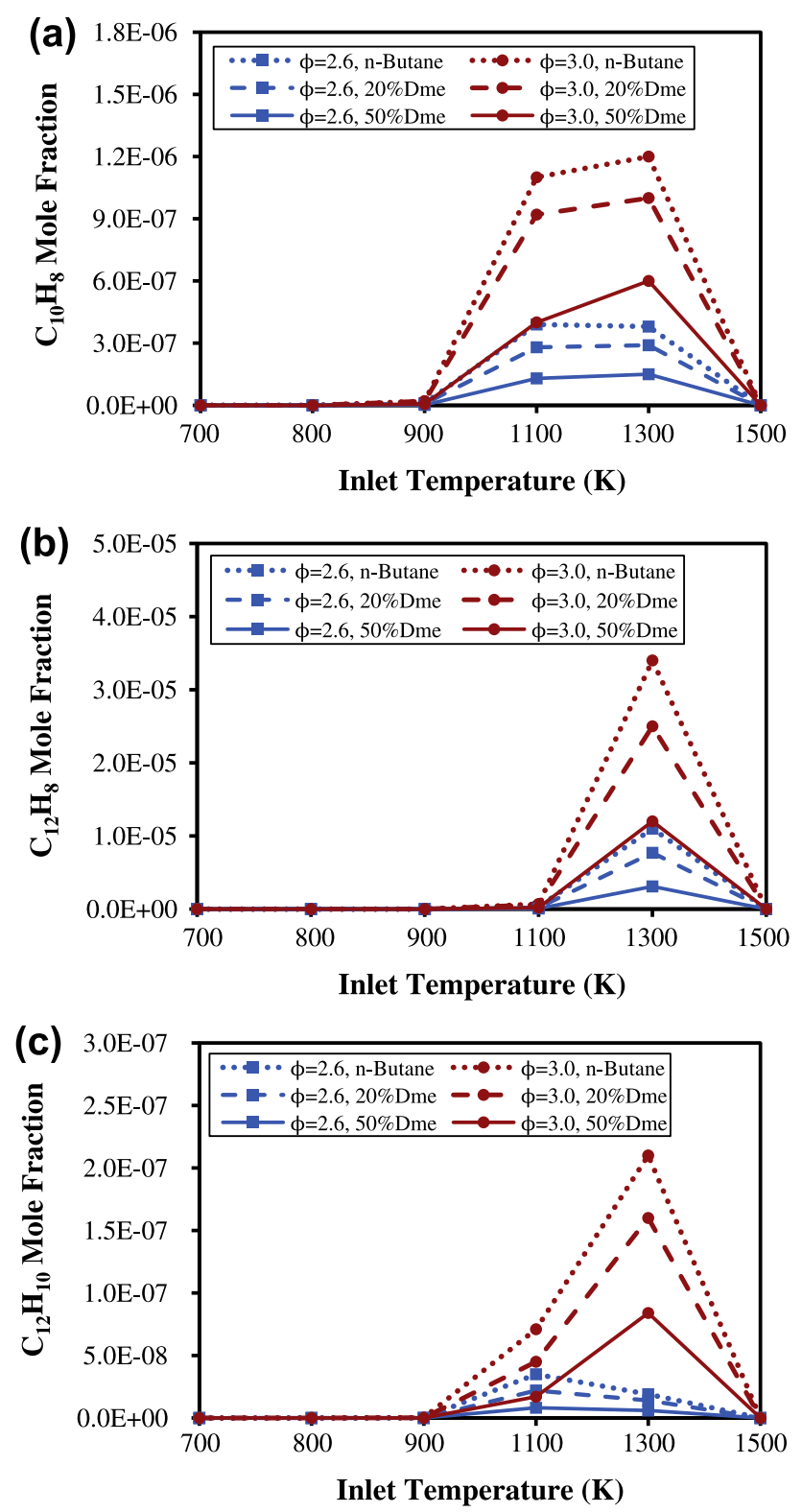

Fig. 12. Mole fractions of (a) naphthalene, (b) acenaphthylene, and (c) biphenyl at the reactor outlet for different inlet temperatures.

was increased. Increasing equivalence ratio increased the mole fraction of $\mathrm{CO}$ and decreased the mole fraction of $\mathrm{CO}_{2}$.

Methane $\left(\mathrm{CH}_{4}\right)$, ethane $\left(\mathrm{C}_{2} \mathrm{H}_{6}\right)$, and propane $\left(\mathrm{C}_{3} \mathrm{H}_{8}\right)$ are minor oxidation products which are alkanes with smaller carbon numbers than butane, and they indicate $C_{1}, C_{2}$, and $C_{3}$ oxidation chemistries, respectively. Methane is also important since it is associated with climate change and global warming [26]. Mole fractions of methane, ethane, and propane at the reactor outlet are given in Fig. 7a-c, respectively. Mole fraction of methane did not seem to be affected by the mole fraction of DME significantly. However, mole fractions of ethane and propane increased with increasing DME percentage. In our mechanism, ethane and propane were considered to be mainly produced by the reactions $\mathrm{CH}_{3}+\mathrm{CH}_{3}(+\mathrm{M})=\mathrm{C}_{2} \mathrm{H}_{6}(+\mathrm{M})$ and $\mathrm{C}_{2} \mathrm{H}_{5}+\mathrm{CH}_{3}(+\mathrm{M})=\mathrm{C}_{3} \mathrm{H}_{8}(+\mathrm{M})$, respectively. The increase in the methyl $\left(\mathrm{CH}_{3}\right)$ radicals due to decomposition of DME $\left(\mathrm{CH}_{3} \mathrm{OCH}_{3}\right)$ was considered to increase the interaction between these methyl radicals rather than interactions with other radicals, resulting in increases in the formations of ethane and propane, instead of methane. Increasing equivalence ratio 
resulted in slight increases in mole fractions of methane, ethane, and propane. Maximum mole fractions of ethane and propane at the reactor outlet were observed around $800{ }^{\circ} \mathrm{K}$, and the maximum mole fraction of methane was observed around $900{ }^{\circ} \mathrm{K}$.

Although DME is known to reduce the formations of several toxic oxidation products when used as a fuel additive, in previous studies it was shown that DME addition to butane and butane/propane mixtures increased the formation of another toxic species, formaldehyde [4]. The mole fractions of formaldehyde obtained in this study for different mole fractions of DME and two different equivalence ratios are shown in Fig. 8a. Acetaldehyde $\left(\mathrm{C}_{2} \mathrm{H}_{4} \mathrm{O}\right)$ is another aldehyde with two carbons and its mole fractions at the reactor outlet are given in Fig. $8 \mathrm{~b}$. Both aldehydes were observed to increase as the DME percentage was increased. The oxygenated structure of DME promoted the formations of these oxygenated species. In our mechanism, the increase in the mole fraction of formaldehyde was considered to be resulting from the reactions $\mathrm{CH}_{3}+\mathrm{OH}=\mathrm{CH}_{2} \mathrm{O}+\mathrm{H}_{2}, \quad \mathrm{CH}_{3} \mathrm{O}(+\mathrm{M})=\mathrm{CH}_{2} \mathrm{O}+\mathrm{H}(+\mathrm{M})$, and $\mathrm{CH}_{2}$ $\mathrm{OH}+\mathrm{O}_{2}=\mathrm{CH}_{2} \mathrm{O}+\mathrm{HO}_{2}$, due to the oxidation chemistry of DME. The increase in the mole fraction of acetaldehyde might be related to the reactions $\mathrm{CH}_{3}+\mathrm{HCO}=\mathrm{C}_{2} \mathrm{H}_{4} \mathrm{O}$ and $\mathrm{pC}_{3} \mathrm{H}_{5}+\mathrm{O}_{2}=\mathrm{C}_{2} \mathrm{H}_{4} \mathrm{O}+\mathrm{HCO}$, due to the oxygenated structure of DME and the increase in the $\mathrm{CH}_{3}$ radical concentration. The effect of equivalence ratio did not seem to be significant under the conditions studied. The maximum mole fractions of these species were observed at around inlet temperatures of $800{ }^{\circ} \mathrm{K}$.

PAHs constitute an important class of toxic species from the combustion of hydrocarbon fuels. They are high molecular weight aromatic species composed of two or more aromatic benzene $\left(\mathrm{C}_{6} \mathrm{H}_{6}\right)$ rings and some members of PAHs are known to be mutagenic or carcinogenic. They are also precursors of soot formation. Formations of aromatic species and PAHs occur at fuel-rich conditions. Some minor oxidation products are known to be the precursors of formations of aromatic species and PAHs [27]. In this study, among these precursors, two-carbon-number acetylene $\left(\mathrm{C}_{2} \mathrm{H}_{2}\right)$, three-carbon-number propargyl $\left(\mathrm{C}_{3} \mathrm{H}_{3}\right)$, four-carbon-number diacetylene $\left(\mathrm{C}_{4} \mathrm{H}_{2}\right)$, and vinylacetylene $\left(\mathrm{C}_{4} \mathrm{H}_{4}\right)$, and five-carbonnumber cyclopentadiene $\left(\mathrm{c}-\mathrm{C}_{5} \mathrm{H}_{6}\right)$ were investigated.

Fig. 9a shows the mole fractions of acetylene at the reactor outlet. Increasing DME mole fraction decreased mole fractions of acetylene. Acetylene is known to react with $C_{4}$ species to form benzene and other aromatic rings, and it also reacts with aromatic species to form larger PAHs [28,29]. According to our mechanism, as DME was added, the reactions of $\mathrm{C}_{2} \mathrm{H}_{2}$ with $\mathrm{O}$ and $\mathrm{OH}$ radicals and $\mathrm{O}_{2}$, producing smaller $\mathrm{C}_{2}$ and $\mathrm{C}_{1}$ species, were considered to lower the mole fraction of $\mathrm{C}_{2} \mathrm{H}_{2}$. Fig. $9 \mathrm{~b}$ shows the mole fractions of propargyl at the reactor outlet. Propargyl is known to react with other $C_{3}$ species to form aromatic rings [30,31], and increasing DME mole fraction slightly decreased mole fractions of propargyl.

Fig. 10a and $\mathrm{b}$ shows the mole fractions of diacetylene and vinylacetylene, respectively. These two acetylenic molecules are also suggested as precursors of PAHs in the literature [28,29]. Increasing DME percentage decreased mole fractions of these two species. Diacetylene was considered to be produced in lower amounts from acetylene by the reaction $\mathrm{C}_{2} \mathrm{H}+\mathrm{C}_{2} \mathrm{H}_{2}=\mathrm{C}_{4} \mathrm{H}_{2}+\mathrm{H}$, according to the mechanism developed, since the mole fraction of acetylene was also decreased. Similarly, vinylacetylene production by the reaction $\mathrm{C}_{2} \mathrm{H}_{3}+\mathrm{C}_{2} \mathrm{H}_{2}=\mathrm{C}_{4} \mathrm{H}_{2}+\mathrm{H}$ was decreased with the decrease in the mole fraction of acetylene. Fig. 10c shows the mole fractions of cyclopentadiene at the reactor outlet. Increasing DME mole fraction also decreased mole fraction of cyclopentadiene. Similar to diacetylene and vinylacetylene, cyclopentadiene was also formed by the reaction $\mathrm{aC}_{3} \mathrm{H}_{5}+\mathrm{C}_{2} \mathrm{H}_{2}=\mathrm{c}-\mathrm{C}_{5} \mathrm{H}_{6}+\mathrm{H}$ from acetylene in lower amounts, according to our mechanism, with the addition of DME.

Increasing equivalence ratio increased the mole fractions of the entire precursor species investigated. Maximum mole fractions of acetylene, propargyl, and diacetylene at the reactor outlet occurred at around inlet temperatures of $1300^{\circ} \mathrm{K}$, while maximum mole fractions of vinylacetylene and cyclopentadiene occurred at around inlet temperatures of $900{ }^{\circ} \mathrm{K}$.

Among the aromatic species and PAHs that are formed as a result of oxidation processes, one-ring benzene (Fig. 11a), toluene $\left(\mathrm{C}_{7} \mathrm{H}_{8}\right)$ (Fig. 11b), and indene $\left(\mathrm{C}_{9} \mathrm{H}_{8}\right)$ (Fig. 11c), and two-ring naphthalene $\left(\mathrm{C}_{10} \mathrm{H}_{8}\right)$ (Fig. 12a), acenaphthylene $\left(\mathrm{C}_{12} \mathrm{H}_{8}\right)$ (Fig. 12b), and biphenyl $\left(\mathrm{C}_{12} \mathrm{H}_{10}\right)$ (Fig. 12c) were investigated. Increasing DME mole fraction decreased the mole fractions of all of these aromatic species. This was an expected result, since DME addition also decreased the mole fractions of the precursor species investigated. Larger PAH molecules that were not investigated in this study are also expected to decrease with the addition of DME, since they are formed by acetylene addition to smaller aromatic rings or by recombination of these smaller rings [27]. Increasing equivalence ratio increased mole fractions of all of these aromatic species. Maximum mole fractions of these aromatic species at the reactor outlet were observed at around inlet temperatures of 1100 and $1300{ }^{\circ} \mathrm{K}$.

\section{Conclusion}

The effects of DME on the formations of various products from n-butane oxidation were investigated by detailed chemical kinetic modeling. Two different DME concentrations and two fuel-rich equivalence ratios were studied for six different values of reactor inlet temperatures. Oxidation process was carried out in an adiabatic tubular reactor under constant atmospheric-pressure condition. The results were compared with those obtained for the oxidation of pure n-butane.

The addition of DME decreased the formations of toxic species such as CO, aromatic species, and PAHs, released from the oxidation of n-butane. However, the mole fractions of formaldehyde and acetaldehyde were increased.

Mole fractions of $\mathrm{CO}$, methane, aromatic species, and PAHs were increased with an increase in the equivalence ratio. The effects of equivalence ratio on the mole fractions of formaldehyde and acetaldehyde were not significant under the conditions studied.

\section{Acknowledgements}

We would like to thank State Planning Organization (2003K 120690) and Izmir Institute of Technology Scientific Research fund (2008 IYTE 11) for financial supports.

\section{References}

[1] Lafleur AL, Longwell JP, Marr JA, Monchamp PA, Plummer EF, Thilly WG, et al. Bacterial and human cell mutagenity study of some C18H10 cyclopenta-fused polycyclic aromatic hydrocarbons associated with fossil fuels combustion. Environ Health Perspect 1993:101:146-53.

[2] Fleisch TH, Basu A, Sills RA. Introduction and advancement of a new clean global fuel: the status of DME developments in China and beyond. J Nat Gas Sci Eng 2012;9:94-107.

[3] Sorenson SC. Dimethyl ether in diesel engines: progress and perspectives. J Eng Gas Turbines Power 2001;123:652-8.

[4] Marchionna M, Patrini R, Sanfilippo D, Migliavacca G. Fundamental investigations on di-methyl ether (DME) as LPG substitute or make-up for domestic uses. Fuel Process Technol 2008;89:1255-61.

[5] Frye CA, Boehman AL, Tjim PJA. Comparison of CO and NO emissions from propane, n-butane, and dimethyl ether premixed flames. Energy Fuel 1999;13:650-4

[6] Jie L, Shenghua L, Yi L, Yanju W, Guangle L, Zan Z. Regulated and nonregulated emissions from a dimethyl ether powered compression ignition engine. Energy Fuel 2010;24:2465-9.

[7] Xinling L, Zhen H. Emission reduction potential of using gas-to-liquid and dimethyl ether fuels on a turbocharged diesel engine. Sci Total Environ 2009;407:2234-44.

[8] Lee S, Oh S, Choi Y, Kang K. Performance and emission characteristics of a $\mathrm{CI}$ engine operated with n-butane blended DME fuel. Appl Therm Eng 2011;31:1929-35. 
[9] Arcoumanis C, Bae C, Crookes R, Kinoshita E. The potential of di-methyl ether (DME) as an alternative fuel for compression-ignition engines: a review. Fuel 2008;87:1014-30.

[10] Erdener H, Arinan A, Orman S. Future fossil fuel alternative; di-methyl ether (DME) a review. Int J Energy Res 2011;1:252-8.

[11] Lee S, Oh S, Choi Y. Performance and emission characteristics of an SI engine operated with DME blended LPG fuel. Fuel 2009;88:1009-15.

12] Lee S, Oh S, Choi Y, Kang K. Effect of n-butane and propane on performance and emission characteristics of an SI engine operated with DME-blended LPG fuel. Fuel 2011;90:1674-80.

[13] Ji C, Liang C, Wang S. Investigation on combustion and emissions of DME/ gasoline mixtures in a spark-ignition engine. Fuel 2011;90:1133-8.

[14] Liang C, Ji C, Liu X. Combustion and performance of a DME-enriched sparkignited methanol engine at idle condition. Appl Energy 2011;88:3704-11.

[15] Liang C, Ji C, Gao B, Liu X, Zhu Y. Investigation on the performance of a spark ignited ethanol engine with DME enrichment. Energy Convers Manage 2012;58:19-25.

[16] Song KH, Nag P, Litzinger TA, Haworth DC. Effects of oxygenated additives on aromatic species in fuel-rich, premixed ethane combustion: a modeling study. Combust Flame 2003;135:341-9.

[17] Yoon SS, Anh DH, Chung SH. Synergistic effect of mixing dimethyl ether with methane, ethane, propane, and ethylene fuels on polycyclic aromatic hydrocarbon and soot formation. Combust Flame 2008;154:368-77.

[18] McEnally CS, Pfefferle LD. The effects of dimethyl ether and ethanol on benzene and soot formation in ethylene nonpremixed flames. Proc Combust Inst 2007;31:603-10.

[19] Marinov NM, Pitz WJ, Westbrook CK, Vincitore AM, Castaldi MJ, Senkan SM et al. Aromatic and polycyclic aromatic hydrocarbon formation in a laminar premixed n-butane flame. Combust Flame 1998;114:192-213.
[20] Kaiser EW, Wallington TJ, Hurley MD, Platz J, Curran HJ, Pitz WJ, et al. Experimental and modeling study of premixed atmospheric-pressure dimethyl ether-air flames. J Phys Chem A 2000;104:8194-206.

[21] Bekat T. Effects of dimethyl ether on n-butane oxidation. Master of science thesis. Izmir Institute of Technology, Graduate School of Engineering and Sciences; 2011.

[22] Chakir A, Cathonnet M, Boettner JC, Gaillard F. Kinetic study of n-butane oxidation. Combust Sci Technol 1989;65:207-30.

[23] Fischer SL, Dryer FL, Curran HJ. The reaction kinetics of dimethyl ether. I: Hightemperature pyrolysis and oxidation in flow reactors. Int J Chem Kinet 2000;32:713-40.

[24] CHEMKIN-PRO. Reaction design: San Diego; 2008.

[25] Levenspiel O. Chemical reaction engineering. 3rd ed. New Jersey: John Wiley \& Sons Inc.; 1999.

[26] EPA, U.S. Environmental Protection Agency. U.S. Greenhouse Gas Inventory Report, Report no. EPA430-R-11-005; 2011.

[27] Richter H, Howard JB. Formation of polycyclic aromatic hydrocarbons and their growth to soot - a review of chemical reaction pathways. Prog Energy Combust Sci 2000;26:565-608.

[28] Cole JA, Bittner JD, Longwell JP, Howard JB. Formation mechanisms of aromatic compounds in aliphatic flames. Combust Flame 1984;56:51-70.

[29] Bartok W, Sarofim AF. Fossil fuel combustion: a source book. WileyInterscience; 1991.

[30] Stein S, Walker JA, Suryan MM, Fahr A. A new path to benzene in flames. Symp (Int) Combust 1991;23:85-90.

[31] Dagaut P, Cathonnet M. A comparative study of the kinetics of benzene formation from unsaturated $\mathrm{C} 2-\mathrm{C} 4$ hydrocarbons. Combust Flame 1998;113:620-3 